\title{
Peran Permainan Tradisional dalam Membentuk Karakter Anak Usia 4-6 Tahun
}

\author{
Yuli Maghfiroh ${ }^{1 *}$ \\ ${ }^{1}$ FKIP, Universitas Kristen Satya Wacana, Jl. Diponegoro No. 52-60 \\ *e-mail: yulimaghfiroh31@gmail.com
}

Abstract. The Role of Traditional Games in Shaping The Character of 4 - 6 Year Old Children. The background of this research is the number of modern games addiction that adversely affect the lives of children. The purpose of this research was to find out the role of traditional games in shaping the character of early childhood. The research methode was literature study. Data were collected by reading various journals and taking notes. Data were analyzed by using three interactive model, namely reducing data, displaying data, and drawing conclusions. Data validity used triangulation process. The results obtained that traditional games have a role in the formation of children's characters, namely honesty, discipline, hard work, creative, independent, communicative, responsibility and so forth.

Keywords: traditional games, character, early childhood

Abstrak. Peran Permainan Tradisional dalam Membentuk Karakter Anak Usia 46 tahun. Penelitian ini dilatar belakangi oleh banyaknya kasus dikarenakan kecanduan permainan modern yang berdampak buruk pada kehidupan anak.Tujuan dari penulisan karya ilmiah ini adalah untuk mengetahui peran permainan tradisional dalam membentuk karakter anak usia dini. Jenis penelitian yang digunakan adalah studi pustaka. Pengumpulan data dilakukan dengan cara mengumpulkan data-data dari berbagai jurnal dan mencatat. Analisis data menggunakan tiga analisis model interaktif yaitu dengan cara mereduksi data, mendisplay data, dan gambaran kesimpulan. Validitas data menggunakan trianggulasi data. Hasil analisis yang diperoleh adalah permainan tradisional memiliki peran dalam pembentukan karakter anak. Karakter yang dapat terbentuk antara lain jujur, disiplin, kerja keras, kreatif, mandiri, komunikatif, tanggung jawab dan lain sebagainya.

Kata Kunci: permainan tradisional, karakter, anak usia dini 
Jurnal Pendidikan Anak, April 2020, p : 1-8 E-ISSN: 2580-9504
Vol. 6, No. 1

DOI:

\section{PENDAHULUAN}

Bermain merupakan kebutuhan pokok bagi anak. Mayesti (Sujiono, 2009) mengemukakan bahwa bermain adalah kegiatan yang anak-anak lakukan sepanjang hari karena bagi anak bermain adalah hidup dan hidup adalah permainan. Pada masa serba teknologi sangat mempengaruhi segala bidang kehidupan, tak terkecuali pada aktivitas anak dalam bermain. Sekarang ini anak-anak cenderung lebih sering memainkan permainan modern seperti Playstation (PS), games online, dan video games dibandingkan dengan melakukan permainan tradisional di halaman. Anakanak cenderung lebih tertarik pada permainan modern yang dikemas semenarik mungkin dengan menyajikan gambar-gambar serta musik sebagai pendukung yang sangat menyenangkan. Hal ini mengakibatkan anak kecanduan terhadap permainan modern. Selain itu telah banyak kasus dikarenakan kecanduan permainan modern yang berdampak buruk pada kehidupan anak. Setelah kecanduan anak akan menjadi individualisme dan menjadikan permainan modern menjadi temannya. Hal ini sejalan dengan salah satu penelitian oleh Novitasari (2016) penggunaan gadget pada anak usia dini menyebutkan bahwa "pemakaian gadget lebih menyenangkan dibandingkan dengan bermain dengan temann sebayanya. Hal ini tak lepas oleh berbagai aplikasi permainan yang terdapat pada gadget anak-anak ini, yang tentunya lebih menarik perhatian anak-anak ini dibandingkan dengan permainanpermainan yang terdapat di lingkungan sekitar. Selain itu juga, orang tua meng"iya"kan bahwa saat anak-anaknya bermain gadget cenderung anak-anak ini diam di depan gadgetnya masing-masing tanpa memperdulikan dunia sekitarnya".

Dengan adanya permainan modern, orang tua cenderung tidak mengenalkan permainan tradisional yang dulu dimainkannya. Orang tua justru memberikan fasilitas kepada anak untuk bermain permainan modern karena dianggap praktis. Akibatnya permainan tradisional mulai ditinggalkan. Padahal jika dilihat lebih lanjut permainan tradisional sangat membantu anak dalam mengembangkan segala aspek, karena permainan tradisional banyak mengandung nilai-nilai yang bermakna kehidupan. Selain dapat mengembangkan segala aspek dalam diri anak, dengan melakukan permainan tradisional juga dapat melestarikan budaya lokal. Permainan tradisional pada umumnya dimainkan secara berkelompok atau minimal dua orang. Hasil penelitian Kurniati (2011:13) menunjukkan bahwa permainan anak tradisional dapat mestimulasi anak dalam mengembangkan kerjasama, membantu anak menyesuaikan diri, saling berinteraksi secara positif, dapat mengkondisikan anak dalam mengontrol diri, mengembangkan sikap empati terhadap teman, menaati aturan, serta menghargai orang lain.

Jika dilihat lebih lanjut permainan tradisional sangat bermanfaat bagi anak terutama anak usia 4 - 6 tahun. Pada usia $4-6$ tahun adalah awal anak mulai terjun ke lingkungan sekitar, seperti bermain, sekolah, dll. Pada saat usia $4-6$ tahun anak akan belajar banyak hal. Menurut Berk (dalam Sujiono, 2009, hlm. 6) bahwa anak usia dini adalah anak yang berada pada rentang usia 0-8 tahun dan pada masa ini anak berada pada rentang yang sangat pesat dan unggul dalam perkembangannya. Pada usia inilah kesempatan untuk membentuk karakter pada anak, sehingga dikemudian hari tidak terdapat penyimpangan perilaku.

Karakter merupakan perilaku yang ditunjukkan oleh seseorang dalam kehidupan sehari-hari yang mempunyai kecenderungan kearah positif maupun 
Jurnal Pendidikan Anak, April 2020, p : 1-8 E-ISSN: 2580-9504
Vol. 6, No. 1

DOI: negatif (Utama, 2011: 02). Pendidikan karakter merupakan pendidikan yang melibatkan penanaman pengetahuan, kecintaan, dan penanaman perilaku kebaikan yang menjadi sebuah pola kebiasaan pada pendidikan anak usia dini, yaitu nilai-nilai yang dipandang sangat penting dikenalkan dan diinternalisasikan kedalam perilaku mereka, yang mencakup: kecintaan terhadap Tuhan Yang Maha Esa; kejujuran; disiplin; toleransi dan cinta damai; percaya diri; mandiri; tolong menolong, kerjasama, dan gotong royong; hormat dan sopan-santun; tanggungjawab; kerja keras; kepemimpinan dan keadilan; kreatif; rendah hati; peduli lingkungan; serta cinta bangsa dan Tanah Air (Ditbin PAUD, 2011b).

Tujuan dari penelitian ini adalah untuk mengetahui peran permainan tradisional dalam pembentukan karakter anak usia 4-6 tahun. Yang bisa diperoleh dari penelitian ini adalah mendapat gambaran manfaat dari permainan tradisional dalam membentuk karakter anak. Berdasarkan diatas, diajukan suatu hipotesis yaitu permainan tradisional memiliki peran dalam pembentukan karakter anak

\section{METODE}

Penelitian ini dilakukan dengan menggunakan metode kajian pustaka. Menurut Zed (2004) mengemukakan riset pustaka tidak hanya sekedar urusan membaca dan mencatat literatur atau buku-buku sebagaimana yang sering dipahami banyak orang selama ini, apa yang disebut riset pustaka atau sering disebut studi pustaka, ialah rangkaian kegiatan yang berkenaan dengan metode pengumpulan data pustaka, membaca dan mencatat serta mengelola bahan penelitian. Alasan menggunakan metode kajian pustaka adalah untuk menginformasikan hasil-hasil penelitian terdahulu dan mengisi celah yang ada pada penelitian sebelumnya. Teknik pengumpulan data dilakukan dengan cara menyimak dan mencatat. Data yang diperoleh diambil dari berbagai jurnal yaitu jurnal pendidikan karakter, ATIKAN, cakrawala dini, jurnal ilmu keolahragaan, jurnal obsesi, Tadbir, dan jurnal empowerment. Analisis data menggunakan tiga analisis model interaktif yaitu dengan cara mereduksi data, mendisplay data, dan gambaran kesimpulan. Validitas data menggunakan trianggulasi data.

\section{HASIL DAN PEMBAHASAN}

Berdasarkan studi literatur yang telah dilakukan ternyata permainan tradisional memiliki peran dalam membentuk karakter anak usia 4-6 tahun. Bahkan pembentukan karakter ini terjadi begitu saja dan tidak disadari.

Permainan tradisional secara tidak sadar dapat membentuk karakter anak. Permainan tradisional dilakukan minimal oleh 2 orang, bahkan bisa jadi berkelompok. Dalam permainan berkelompok itu akan menghasilkan pesan moral. Menurut Sudrajat, dkk (2015) bahwa beberapa pesan moral yang dapat disampaikan oleh permainan tradisional:

a. Permainan tradisional mengajarkan untuk berbagi kepada 4esame teman, karena permainan menuntut mereka untuk berinteraksi langsung dengan lawan main.

b. Masing-masing pemain harus dapat bersikap sportif pada setiap permaian yang dilakukan dan harus dapat menerima jika dia kalah.

c. Setiap pemain harus menyelesaikan setiap permainan dari awal sampai akhir permainan, tidak boleh berhenti 
Jurnal Pendidikan Anak, April 2020, p : 1-8 E-ISSN: 2580-9504

di tengah permainan (tidak boleh putus asa).

d. Masing-masing pemain akan berpikir kreatif terhadap hal-hal yang ada disekelilingnya sehingga diharapkan kelak anakanak tersebut menjadi manusia dewasa yang kreatif (dalam hal positif tentunya).

Berdasarkan pesan moral permainan tradisional yang dikemukakan oleh sudrajat, dkk, dapat dilihat bahwa permainan tradisional memiliki pesan moral yang sangat berguna bagi kehidupannya kelak. Dengan permainan tradisional akan terjadi interaksi antar teman yang memiliki kepribadian yang berbeda-beda, sehingga akan menumbuhkan sikap saling memahami dan mengasihi. Dapat terjadi juga dalam berbagi alat main. Ketika bermain permainan berlangsung setiap anak akan bermain sampai akhir permainan, tidak boleh berhenti ditengah jalan jika dirasa sudah kalah, dengan ini anak akan bersungguh-sungguh dalam bermain dan pantang menyerah. Sungguh-sungguh dalam melakukan permainan ini akan diimbangi dengan munculnya ide-ide kreatif anak agar bisa memenangkan permainan. Dalam permainan juga harus dilakukan dengan sportif, mengakui jika kalah, dan menerima dengan lapang dada.

Dapat dilihat bahwa permainan tradisional mengandung nilai moral yang di dalamnya tersimpan nilai-nilai karakter. Iswinarti (2010:6) mengemukakan bahwa hingga pada anak usia sekolah bermain bagi anak memiliki arti yang sangat penting, adapun nilai-nilai penting dalam bermain bagi anak, yaitu sebagai berikut.
a. Meningkatkan kemampuan problem solving pada anak.
b. Menstimulasi perkembangan bahasa dan kemampuan verbal.
c. Mengembangkan keterampilan sosial.

Vol. 6, No. 1

DOI:

\section{d. Merupakan wadah pengekspresian emosi.}

Berdasarkan nilai-nilai penting dalam bermain yang disamapaikan diatas, dapat dilihat dengan melakukan permainan tradisional dapat meningkatkan kemampuan problem solving pada anak. Dengan bermain permainan tradisional maka anak akan saling beradu pikiran maupun pendapat, dan si anak juga yang akan menyelesaikan masalah tersebut. Dengan melakukan permainan tradisional anak akan saling berkomunikasi yang secara tidak sadar dapat mengasah kemampuannya dalam berbahasa dan menambah kosa kata. Permainan tradisional dimainkan secara bersama-sama, dengan ini maka anak akan mengembangkan keterampilan sosialnya sendiri melalui pengalamannya. Ketika bermain anak akan mecurahkan segala emosinya, selain itu mereka akan mengembangkan sikap sadar diri yang merupakan emosi kompleks, seperti rasa malu, bangga, dan lain sebagainya.

Menurut hasil penelitian Zafirah, et.al. (2018) secara nyata telah membuktikan bahwa penggunaan media pembelajaran seperti permainan tradisional congkak sebagai media pembelajaran dapat menanamkan nilainilai karakter terhadap peserta didik. Berdasarkan data kualitatif (wawancara) serta didukung oleh data kuantitatif (angket) secara umum baik informan maupun responden menyepakati bahwa terdapat sembilan nilai-nilai karakter yang terdapat di dalam permaiann congkak, sembilan nilai tersebut adalah kejujuran, disiplin, kerja keras, kreatif, rasa ingin tahu, mandiri, komunikatif, tanggung jawab dan menghargai prestasi.

Berikut beberapa permainan tradisional dan karakter yang dapat tumbuh: 
Jurnal Pendidikan Anak, April 2020, p : 1-8 E-ISSN: 2580-9504
Vol. 6, No. 1

DOI:

\section{Kelereng}

Kelereng adalah alat permainan yang berbentuk bulat dan berukuran kecil. Permainan kelereng ini minimal dimainkan oleh 2 orang, dan tidak terdapat batasan maksimal orang dalam memainkan permainan kelereng. Karakter yang dapat tercipta melalui permainan kelereng adalah kejujuran yang terbentuk dari bermain dengan sportif; disiplin yang terbentuk dari urutan dalam memainkan; hormat dan sopan-santun terbentuk dari tidak meremehkan lawan ketika menang; kerja keras dan kreatif ketika bermain memikirkan suatu strategi untuk menang dan berusaha dengan sungguh-sungguh; bertanggungjawab untuk menyelesaikan permainan, dan masih banyak lagi.

\section{Congklak}

Congklak adalah alat permainan yang terdiri dari 16 lubang, yang memainkannya menggunakan biji, batu, atau benda kecil yang ada disekitarnya. Permainan congklak hanya bisa dimainkan oleh dua orang. Karakter yang dapat tumbuh melalui permainan ini adalah kejujuran yang terbentuk ketika siswa jujur dalam mendistribusikan biji atau batu; menerima jika mengalami kekalahan; percaya diri bahwa dengan kemampuannya bisa menang dibuktikannya dengan melanjutkan permainan ke dua setelah kalah dalam permainan pertama; kreatif yang terbentuk dalam mengatur strategi untuk bisa memenangkan permainan; bertanggungjawab untuk menyelesaikan permainan, dan masih banyak lagi.

\section{Ular naga}

Ular naga adalah permainan yang dimainkan sambil menyanyikan lagu ular naga dan hanya bisa dimainkan oleh beberapa orang. Karakter yang bisa tumbuh dalam permainan ini adalah kerjasama yang tercipta ketika bekerjasama agar tidak dapat ditangkap; jujur yang tercipta dari jika sudah ditangkap tidak melakukan pengelakan; bertanggungjawab untuk menyelesaikan permainan, dan masih banyak lagi.

\section{Petak umpet}

Petak umpet adalah permainan yang dimainkan dengan cara satu orang berjaga yang bertugas menghitung dan mencari pengganti untuk berjaga, sedangkan anak yang lain sembunyi yang akan dicari oleh penjaga. Karakter yang dapat terbentuk melalui permainan ini adalah jujur terbentuk ketika ditemukan mengaku bukan mengelak; toleransi dan cinta damai terbentuk ketika permainan berlangsung tidak saling mengusir ketika sembunyi ditempat yang sama; kerjasama terbentuk ketika saling mengetahui tempat persembunyian teman tetapi ketika tertangkap tidak memberitahu kepada penjaga; kreatif terbentuk ketika memikirkan strategi berpindah dan menemukan tempat persembunyian yang aman; bertanggungjawab untuk menyelesaikan permainan, dan masih banyak lagi.

\section{Lompat tali}

Lompat tali adalah permainan yang dimainkan dengan menggunakan alat berupa tali atau karet yang dianyam, permainan ini dilakukan minimal oleh 3 orang. Karakter yang bisa terbentuk ketika melakukan permainan ini adalah jujur terbentuk ketika melakukan permainan dilakukan dengan sportif; toleransi dan cinta damai terbentuk ketika mengalami kekalahan menerima dengan ikhlas, jika menang tidak mencemooh temannya yang kalah; kerja keras terbentuk ketika mencari jarak lari agar bisa melompat diatas tali dan gigih untuk memenangkan permainan; disiplin yang terbentuk ketika mematuhi urutan bermain, dan masih banyak lagi.

Melalui karakter yang membentuk anak melalui permainan tradisional, maka 
Jurnal Pendidikan Anak, April 2020, p : 1-8 E-ISSN: 2580-9504
Vol. 6, No. 1

DOI: dapat diperoleh dampak dari pembentukan karakter melalui permainan tradisional. Iswinarti (2010) menyebutkan bahwa peran bermain pada anak berdampak pada sejumlah bidang kehidupan anak, yaitu sebagai berikut.

a. Bermain mempunyai peran yang penting dalam belajar. Dalam hal ini, bermain dapat melengkapi kegiatan sekolah anak, yang dapat memberi kesempatan kepada anak untuk memahami, meresapi, dan memberi arti kepada apa yang mereka pelajari dalam seting pendidikan formal. Secara khusus, bermain menjadi penting yaitu membantu anak untuk memperoleh "bukan informasi khusus, tetapi mindset umum dalam pemecahan masalah".

b. Bermain dapat mendukung perkembangan fisik dan kesehatan mental yang baik. Bermain memfasilitasi anak dalam beraktivitas fisik, meliputi kegiatan berolah raga, yang memungkinkan meningkatnya koordinasi dan keseimbangan tubuh, serta mengembangkan keterampilan dalam pertumbuhan anak. Adapun sumbangan untuk kesehatan mental adalah membantu anak untuk membangun dan mengembangkan resiliensi (daya tahan) terhadap tekanan dalam hidup.

c. Bermain memberi kesempatan untuk menguji anak dalam mengahadapi tantangan dan bahaya.

Permainan tradisional juga memiliki dampak bagi perkembangan anak. Beberapa dampak diantaranya adalah sebagai berikut:

\section{Dampak positif}

1.Anak memiliki kemampuan bersosialisasi

Melalui aktifitas kerja sama dalam melakukan permainan tradisional, kemampuan sosialisasi akan terasah. Akan tercipta sikap saling memahami, menyayangi, mengasihi, toleransi, dan menghargai.

2.Tidak menjadi anak yang egosentris

Pada usia 4 sampai 6 tahun yang berada pada tahap pra operasional. Pada tahap ini anak cenderung egois yang melihat sesuatu berdasarkan pendapatnya, belum memikirkan sudut pandang orang lain. Dengan melakukan permainan tradisional anak akan belajar untuk mengendalikan emosi.

3.Anak akan sehat dan perkembangan fisik anak akan tercapai

Dengan bermain permainan tradisional anak akan berolahraga, olahraga disini tidak dipaksa bahkan dilakukan dengan senang hati. Kemampuan motorik kasar dapat terasah yaitu dengan cara melompat, bergerak, berlari, dan lain sebagainya. Kemampuan motorik halus pun terasah misalnya melipat, merobek, mengupas, menjumput, dan lain sebagainya. Selain itu tulangtulang anak menjadi kuat, dan daya tahan tubuh meningkat.

4.Menjadi anak yang kritis dan kreatif

Dalam melakukan permainan tradisional, anak akan memikirkan strategi-strategi yang akan dilakukan agar bisa memenangkan permainan. Selain itu anak akan fokus dalam permainan dan jika terdapat sesuatu yang keliru anak akan langsung mengkritisinya.

\section{Dampak Negatif}

Dampak negatifnya anak akan keasikan bermain dan lupa waktu. Permainan tradisional sangat menyenangkan dimainkan, selain itu 
Jurnal Pendidikan Anak, April 2020, p : 1-8 E-ISSN: 2580-9504

banyak teman sehingga menjadikan tidak ingat waktu. Bahkan bisa tidak ingat waktu untuk makan, mandi, beribadah, dan lain sebagainya.

\section{SIMPULAN DAN SARAN}

Berdasarkan pembahasan yang telah diuraikan, maka dapat ditarik kesimpulan bahwa pada usia 4 - 6 tahun anak sedang dalam tahap perkembangan yang sangat pesat. Pada usia inilah waktu yang sangat tepat untuk menanamkan suatu pendidikan. Salah satunya adalah pendidikan karakter.

Permainan tradisional memiliki peran dalam pembentukan karakter anak. Karakter yang dapat terbentuk antara lain adalah jujur, disiplin, kerja keras, kreatif, mandiri, komunikatif, tanggung jawab dan lain sebagainya. Karakter yang terbentuk melalui permainan tradisional berjalan secara tidak sadar, dan inilah yang membuat anak belajar dengan sendirinya tanpa adanya paksaan. Oleh sebab itu permainan tradisional perlu dikembalikan menjadi permainan utama untuk anak agar dapat tercipta anak yang berkarakter dan menjadi generasi bangsa yang berintegritas.

Berdasarkan pembahasan di atas, maka peneliti memberikan saran yaitu bagi orang tua diharapkan dapat mengajarkan permainan tradisional yang dulu pernah dimainkannya, karena permainan tradisional dapat membantu membentuk karakter anak. Bagi guru diharapkan dapat menggunakan permainan tradisional sebagai metode pembelajaran. Bagi peneliti lain, penelitian ini diharapkan dapat sebagai referensi dalam menyusun penelitian yang lebih baik tentang peran permainan tradisional dalam membentuk karakter anak usia $4-6$ tahun.
Vol. 6, No. 1

DOI:

\section{REFERENSI}

Aprinawati, Iis. (2017). Penggunaan Media Gambar Seri untuk Meningkatkan Kemampuan Berbicara Anak Usia Dini. Jurnal Obsesi: Jurnal Pendidikan Anak Usia Dini, 1(1), 72-80.

Asmawati, Luluk. (2015). Gaya Pengasuhan Orangtua untuk Pembentukan Karakter Melalui Penerapan Permainan Tradisional pada Anak Usia Dini, 4 - 5 Tahun. ATIKAN, 5(1).

Beverley, B. 1993. Children's Science, Constructivism and Learning in Science (Second Edition). Victoria: Deakin University Press.

Fadli, Z. (2015). Membentuk Karakter Anak dengan Olahraga Tradisional. Jurnal Ilmu Keolahragaan, 14 (2), 49-56.

Iswinarti. (2018). Permainan Tradisional: Prosedur dan Analisis Manfaat Psikologis. Malang: UMM Press.

Miller, S. (1993). Children's Alternative Frameworks: Should be Directly Addresses in Science Instruction? Jurnal of Research in Science Teahing, 30 (3): 233-248.

Nadjamuddin, Asriyati. (2016). Membangun Karakter Anak Lewat Permainan Tradisional Daerah Gorontalo. Tadbir: Jurnal Manajemen Pendidikan Islam, 4(2), 74-79.

Noffia, Irma. (2015). Mengembangkan Disiplin Anak Usia Dini Melalui Permainan Tradisional. Cakrawala Dini, 5(2).

Nur, Haerani. (2013). Membangun Karakter Anak Melalui Permainan Anak Tradisional. Jurnal Pendidikan Karakter, (1).

Nurhayati, Iis. (2012). Peran Permainan Tradisional dalam Pembelajaran Anak Usia Dini (Studi di PAUD Geger Sunten, Desa Suntenjaya). 
Jurnal Pendidikan Anak, April 2020, p : 1-8 E-ISSN: 2580-9504

Empowerment; Jurnal Ilmiah Program Studi Pendidikan Luar Sekolah, 1(2), 39-48.

Nuryasana, E., dan Ratna Indarti. (2017). Pengembangan Permainan Tradisional "Bentengan" sebagai Impementasi Pendidikan Karakter di MI Unggulan As'Saadah Surabaya. Seminar Nasional PGSD UNIKAMA.

Pebriana, Putri Hana. (2017). Analisis Penggunaan Gadget terhadap Kemampuan Interaksi Sosial pada Anak Usia Dini. Jurnal Obsesi: Jurnal Pendidikan Anak Usia Dini, 1(1).

Putrantana, Angga Bramansta. (2017). Pembentukan Karakter Siswa Sekolah Dasar melalui Permainan Tradisional pada Pendidikan Jasmani, Olahraga \& Kesehatan.
Vol. 6, No. 1

DOI:

Seminar Nasional Pendidikan Olahraga, 1(1), 235 - 241.

Saukah, A. \& Waseno, M.G. (Eds.). 2002. Menulis Artikel untuk Jurnal Ilmiah (Edisi ke-4, cetakan ke-1). Malang: UM Press.

Sudrajat, Taat Wulandari, dan Agustina Tri Wijayanti. (2015). Muatan Nilai-Nilai Karakter Melalui Permainan Tradisional di Paud Among Siwi, Panggungharjo, Sewon, Bantul. JIPSINDO, 2(1).

Zafirah, Afifah, Fardatil Aini Agusti, Engkizar, Fuady Anwar, A Fajri Alvi, dan Ernawati. (2018). Penanaman Nilai-Nilai Karakter terhadap Peserta Didik Melalui Permainan Congkak sebagai Media Pembelajaran. Jurnal Pendidikan Karakter, (1). 